\title{
Ética e política na potência cênica da Cie Dos à Deux.
}

\section{Ethics and politics in the scenic potency of the Cie Dos à Deux.}

\author{
Desirée Pessoa \\ Universidade Federal do Estado do Rio de Janeiro | Rio de Janeiro, RJ, Brasil. \\ desireepessoa@gmail.com I ORCID: https://orcid.org/0000-0002-3445-6829 \\ DOI: $10.20396 /$ conce.v8i2.8656458. \\ Submetido em: 30/08/2019 | Aceito em: 06/12/2019 | Publicado em: 20/12/2019.
}

\section{Resumo}

Neste estudo, questões relacionadas à ética no teatro contemporâneo são abordadas, a partir do contato com a PALAVRAS-CHAVE Ética. Política. Corpo. Cie Dos à Deux. Ao refletir sobre o espetáculo "Irmãos de Sangue", o texto discute relações entre ética, política e corpo, à luz de pensamentos de Deleuze, Cornago e Pessoa. Assim, evidencia-se a força de vínculos possíveis entre encenação contemporânea, performance e filosofia.
Abstract
In this article, ethics-wise questions in contemporary theater are addressed from the contact with Cie Dos à Deux. By reflecting upon the play "Blood Brothers", the text discusses relations between ethics, politics and body, and its references are the thoughts of Deleuze, Cornago and Pessoa. Thus, it highlights the strength of possible links between contemporary staging, performance and philosophy. KEYWORDS 
Percebo há alguns anos a potência da colisão entre cena contemporânea, performance e filosofia. Com isso, dedico-me ao tema em uma pesquisa artístico-acadêmica que percorreu, até agora, diferentes caminhos e trouxe diversas reverberações em meu trabalho, nos âmbitos da teoria e da prática. No presente texto, tratarei de questões relacionadas à ética que emergem de uma pesquisa mais ampla, realizada junto a alguns coletivos cênicos que apresentam elementos performativos, dentre eles a Cie Dos à Deux, no período entre 2014 e 2018. A observação de ensaios e apresentações de espetáculos da companhia franco-carioca possibilitou a expansão de meu pensamento e discurso sobre a força filosófica da cena contemporânea contaminada pela performance e, por conseguinte, trouxe percepções quanto ao engajamento ético dos corpos em situação cênica performativa.

\section{A Cie Dos à Deux e sua potência cênica}

Da Cie Dos à Deux, tive a oportunidade de assistir, em fevereiro de 2014, no CCBB (Centro Cultural Banco do Brasil) do Rio de Janeiro, o espetáculo

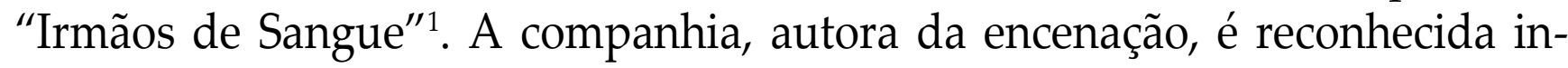
ternacionalmente por seu trabalho corporal e pela ousadia de desenvolver sua trajetória a partir de duas sedes, em países diferentes: Brasil e França. Originada de um encontro entre seus criadores, André Curti e Artur Luanda Ribeiro, atua de maneira continuada nas cidades de Paris e Rio de Janeiro desde 1998 e viaja por inúmeros países com seus espetáculos.

A companhia traz à cena uma identidade poética já conhecida por espectadores assíduos de teatro, com algumas características marcantes que, dentre outros aspectos, denota, segundo Pessoa (2018, p. 72): "uma pesquisa corporal própria, que se desenvolve a partir da dissolução de fronteiras entre o teatro e a dança e funda um tipo de manifestação corporal que, após alguns anos, foi denominada como 'teatro gestual'".

A expressão "teatro gestual", à qual a autora se refere, consiste em um tipo de encenação que, próxima da dança contemporânea, busca criar um vocabu-

\footnotetext{
${ }^{1}$ Ano de estreia: 2013. Ficha técnica: roteiro, encenação, coreografia e cenografia: André Curti e Artur Ribeiro; elenco: Cécile Givernet, Matias Chebel, André Curti e Artur Ribeiro; música original: Fernando Mota; violino: Fran Lausen; marionetes e figurinos: Natacha Belova; acessórios, perucas e maquiagem: Maria Adelia e Marta Rossi (assistidas por Morgan Olivier e Camila Moraes); cenário: Demis Boussu; iluminação: Bertrand Perez e Artur Ribeiro; direção de produção: Nathalie Redant. Informações do website da companhia, disponíveis no link: http://www.dosadeux.com/spip.php?article575\&lang=fr. Último acesso: 30.08.2019, às 13h10min.
} 
lário e formar uma linguagem corporal. É diferente na maneira de interpretar e de articular o movimento, pois sua linguagem favorece o surgimento de um jogo teatral, orgânico e musical. Assim, o teatro gestual, segundo informações obtidas no website da própria companhia, cria a dramaturgia através do corpo das personagens, mas sem ilustrar intenções e situações ${ }^{2}$.

Além dessa, outras características evidentes no trabalho da companhia são: "o rigor perceptível no processo criativo como um todo [...], em que a precisão é um valor notório; uma proposta visual que carrega excelência [...] e a opção por temas relacionados à experiência humana" (PESSOA, 2018, p. 7273).

No caso de "Irmãos de Sangue", a encenação conduz o conjunto de espectadores por um reencontro entre dois irmãos na ocasião da morte do pai. Tem início, então, uma viagem subjetiva ao passado: através da memória. Assim, o espetáculo se estrutura a partir de cenas de infância vividas pelos dois personagens, além de um terceiro irmão que, na fábula construída, é morto em um trágico acidente domiciliar. Em cena, vemos também a figura da mãe, que cria os três filhos em casa, sozinha. O pai, ao morrer, reaproxima os dois irmãos sobreviventes, já adultos maduros e os traz até a mãe agora envelhecida, mas durante toda a infância dos filhos é ausente. A encenação é composta em um ambiente onírico, com cenas lúdicas mescladas a outras alegres, algumas melancólicas e ainda outras muito tristes. Todas as sensações são conduzidas pela abordagem corporal, dada a escolha da companhia, de não trazer a psicologia das personagens ao primeiro plano da cena. Com essa opção, o espectador tem então a possibilidade de criar significados variados às próprias sensações em diversos momentos.

No que se refere ao aspecto formal da encenação, o espetáculo evidencia absoluta precisão e domínio técnico. A dramaturgia não contém um texto falado e o trabalho corporal associado aos elementos visuais garantem uma profusão de belas imagens. A iluminação não é apenas funcional: compõe artisticamente, criando uma atmosfera de ilusionismo em que o jogo se estabelece a partir da constante tensão entre esconder e revelar. Também pelo contato com a iluminação do espetáculo, o público experimenta as densas camadas das relações humanas através de um tema que vincula memória, cronologia,

${ }^{2}$ Informação encontrada no website da companhia, disponível no link: http://www.dosadeux.com/?article280\&lang=pt_br. Último acesso: 30.08.2019, às 13h11min. 
maternidade, infância, amor e crueldade: o do laço sanguíneo. Os elementos visuais garantem, mesclados com o trabalho físico, beleza plástica e magnetismo na cena. A relação com todos os elementos, sobretudo os bonecos, vai além da manipulação e chega à formação de um só corpo. "Irmãos de Sangue" proporciona um arrebatamento ao espectador pelos elementos da poética da companhia. Como reconhece Pessoa (2018), não está na temática dessa encenação sua potência: a questão abordada são as memórias sobre experiências compartilhadas na história de uma família, assunto sobre o qual a maioria das pessoas pode refletir sem dificuldades. "Todavia, a maneira como o assunto é problematizado, a meu ver, é o que faz de "Irmãos de Sangue" uma obra de arte" (PESSOA, 2018, p. 75).

Sabemos que a utilização de elementos visuais variados e solidamente elaborados, por si só, não garante a eficiência de um espetáculo. No trabalho da Dos a Deux, atribuo o bom sucesso de sua poética à ênfase na relação corporal que se estabelece com cada camada de seu espetáculo: suas movimentações são absolutamente precisas e muito demarcadas, o que provém da herança da companhia no campo da dança. No entanto, existe um certo arejamento, um espaço para uma composição cênica que não é coreográfica. Possivelmente, isso se deva à forma como criam as cenas, partindo de improvisações sem destino final. Na poética da companhia, isto significa uma opção pela liberdade na criação. Contudo, o rigor e a precisão técnica sempre presentes são os elementos que asseguram o mencionado arrebatamento por parte dos espectadores. Tive oportunidade de assistir em diversas noites, com diferentes platéias, ao mesmo espetáculo, e sistematicamente vi o público completamente imerso na cena que à sua frente se apresentava.

No decorrer da pesquisa realizada, coletei, ainda, através de entrevistas com os fundadores da companhia, André Curti e Artur Luanda Ribeiro, relatos sobre seu trabalho. No trecho abaixo, extraído de tais entrevistas, podemos perceber, ainda, que a relação entre corpo e visualidade que se dá pelo interesse por uma utilização mais potente de objetos se estende do espetáculo, chegando à concepção de vida dos atores e, portanto, transcorre todo o processo criativo.

André Curti - A relação em cena, [...] na verdade, aí a gente fala de todo o processo, né. A relação com o objeto, ela [...] vem do começo do processo e eu acho que a paixão por objeto no teatro e fora do teatro [...]. Acho que os dois temos isso muito fortee nãoé por acaso que a gente tem um trabalho de objeto fortíssimo, eu acho queéuma coisa queécomum aos dois. 
A relação dos corpos em "Irmãos de Sangue", tanto entre si, quanto com todos os demais elementos do espetáculo, evidencia um trabalho que contempla força muscular, movimentos expansivos, posições de equilíbrio desafiadoras, ritmo, precisão e coordenação motora, e, ao mesmo tempo, denota variadas possibilidades de manifestação expressiva dos corpos em cena. Um desenho preciso e minucioso de cena, em toda a complexidade da visualidade do espetáculo se faz perceptível, contudo, é o acirramento do trabalho corporal que garante o magnetismo do olhar sobre o espetáculo.

Na ocasião em que pude realizar observações sobre o trabalho da companhia para a pesquisa então em andamento, durante temporada de apresentações do espetáculo realizada em São Paulo (novembro/2014), tive a oportunidade de perceber o cotidiano desse coletivo e assistir novamente ao espetáculo, algumas vezes. Neste contexto, verifiquei dois aspectos da ética experimentada pela companhia e fundamentais para o desenvolvimento de sua obra: o primeiro deles consiste no rigor técnico; o segundo, incide no conjunto de práticas que envolvem a noção de encontro especificamente tratada à luz dos conceitos de diferença e repetição. Percebi, ainda, que os dois aspectos se entrelaçam nas ações da companhia.

Ao refletir sobre o primeiro aspecto, que se refere ao rigor técnico, pude perceber que os fundadores da Cie Dos à Deux, André Curti e Artur Luanda Ribeiro, propõem uma cena complexa e somente encerram o processo criativo quando consideram totalmente satisfatório o ponto de chegada. Como exemplo, temos em "Irmãos de Sangue" uma incrível maquinaria que promove, durante a encenação, um acesso do espectador à experiência de visualidade e participação em um ambiente onírico, estabelecido a partir da perfeita sincronia entre iluminação, trilha sonora, corpos dos atores, elementos cenográficos e ação de um contrarregra que atua durante todo o espetáculo. No trecho abaixo, também extraído das entrevistas coletadas, notamos que o rigor acima mencionado está vinculado a um senso de responsabilidade com a presença do espectador.

Artur Luanda Ribeiro - [...] fazer pessoas se sentarem num lugar durante uma hora e meia, desligarem o celular, prestarem atenção, está cada vez mais difícil também. Então, eu tenho uma função muito importante ali, eu não posso fazer qualquer coisa, eu não posso... [...] eu tenho que ter um respeito muito grande por essas pessoas [...]. Eu estou ali por alguma coisa, eu não posso estar só ali, é muito sério o que eu tenho pra dizer [...].

Durante a investigação, ao refletir sobre as palavras de Artur Luanda Ri- 
beiro, percebi que a potência política da obra não estava explícita na concepção do espetáculo, mas fazia parte de sua estrutura. À primeira vista, não consideraria "Irmãos de Sangue" um espetáculo de teatro político, no sentido usual do termo, que se refere a um tipo de teatro que pretende a elucidação de ideias, que "apreende temas discutidos publicamente ou que ele mesmo traz para a discussão, e dessa forma (pelo menos) tem efeito esclarecedor" (LEHMANN, 2009 , p. 2-3). Essa definição não corresponde, de fato, ao espetáculo da Cie Dos à Deux. Todavia, pude experimentar a potência da obra a partir de sua estrutura e perceber que a dimensão política dessa encenação está na transgressão que promove durante sua fruição: o impacto causado aos espectadores, na relação de estesia que se estabelece a partir do rigor e da potencialização do encontro que testemunham é o que desestabiliza, choca e consequentemente, mobiliza o grupo social atingido, isto é, o público. "A estrutura do espetáculo é o fio condutor de uma experiência ética que se expande, abraça e envolve a plateia. É aí que a experiência ética da companhia se converte em potência política" (PESSOA, 2018, p. 76).

Para tratarmos, na presente discussão, da questão do político, torna-se pertinente destacar que a ética, tema caro aqui, e a política, embora não sejam instâncias idênticas, são muito próximas. "A ética é a parte da filosofia que, tradicionalmente, se ocupa com a reflexão sobre os modos de vida, o comportamento individual e as relações em um coletivo" (PESSOA, 2018, p. 76-77). A autora que aqui nos auxilia a compreender a dimensão ética, ainda avalia, sobre a mesma área de produção humana que: "Ela está preocupada com as razões de se desejar uma vida coletiva em que a harmonia é atributo de referência" (ibidem, p. 77). Para Aristóteles (1984), por exemplo, a virtude e a justiça têm participação importante nessa compreensão. A política, por sua parte, se refere "aos cidadãos e ao governo da cidade, àquilo que é público. Assim, a reflexão filosófica sobre a política se dedica à análise da relação entre os sujeitos e a sociedade, à reflexão sobre as formas de poder e os sistemas de governo" (ibidem). Podemos perceber, portanto, que "a ética diz respeito à esfera íntima, ou seja, lida com o outro que é próximo e conhecido. A política se relaciona ao âmbito social, e, assim, lida com aquele que é distante e desconhecido, mas que temos ciência da existência" (ibidem, p. 77).

Aqui se faz necessário destacar que, no contexto da pesquisa que trouxe a esta produção teórica, a ideia de "outro" mais se aproxima daquela que corresponde à noção de "corpo" do que de "sujeito". Ainda em consonância com 
Pessoa (2018, p. 77), “o outro deixa, ele também, de ser compreendido como sujeito e passamos a tratar esta ideia como aberta a todos os elementos da vida e da natureza. Tudo pode ser considerado outro em uma relação". Tais pressupostos têm proveniência em um vínculo ao legado teórico de Gilles Deleuze, e compreendem como significado mais aproximado a ideia de relação, de rede que interliga diversos elementos, em detrimento à visão de "corpo como invólucro de um sujeito" (ibidem, p. 19).

\section{O corpo, o encontro, a ética, a política}

Durante a pesquisa de campo desenvolvida junto à companhia Dos à Deux, pude reconhecer que é por saber da existência e relevância do outro na composição da própria obra que esse coletivo se tornou tão rigoroso com o âmbito estético de seus espetáculos, como vimos nas palavras de Artur Luanda Ribeiro, ao se declarar impossibilitado de agir de outro modo. Nesse sentido, percebo conexões possíveis com o texto de André Lepecki, "No metaplano, o encontro". Nele, o autor reconhece e denuncia, a partir de uma reflexão sobre obras de Michel Serres, Espinosa e Gilles Deleuze, que a humanidade está sofrendo de uma espécie de cacofonia egóica em que muito se fala e pouco ou nada se escuta: “todo mundo fala; ninguém ouve” (LEPECKI, 2013, p. 112).

Lepecki ressalta, após a sinalização inicial, que há, em contrapartida, certa harmonia na vida, ou compreensão, proveniente do encontro, algo que ele define como paralelamente incrível e mundano. Trata-se da experiência do primeiro encontro: duas vidas que têm contato inaugural no plano cacofônico do mundo e vislumbram o toque de uma mão, uma linha de braço, um modo de inclinação do tronco, por exemplo. O autor nos lembra que o mundo mundano oferece bloqueios, evidentemente, como a falação que nada diz e a "circulação que nunca faz passar nada" (ibidem, p. 113), e destaca a advertência de Espinosa quanto a nem todo encontro ser bom: há os que são "puro veneno, que fazem relações por via de decomposições" (ibidem, p. 116). No entanto, ressalta que há contatos em toda parte: o mundo é um campo de interações.

O autor se alia a Deleuze para refletir sobre essa questão e destaca o momento em que um corpo encontra outro, avaliando que há aí a busca por um ponto de diferenciação que não se reduz ao espaço da geometria do encontro: 
contro pode expressar os seus mais puros devires, a sua consistência singular [...]. No encontro, acha-se um entrelugar que apesar de flutuante é totalmente localizável e feito de elementos bem enraizados e corpóreos. No jardim ou praia descobrem em silêncio a ressonância harmônica improvável. (LEPECKI, 2013, p. 116-117.)

Lepecki esclarece, ainda, que designa como encontro aquele que se configura de saber como não ser indigno diante de um acontecimento, de saber fazê-lo acontecer e se desdobrar em mais acontecimentos. O que importa não é, para Lepecki, saber antecipadamente como fazê-lo e sim "o desejo de querer torná-lo pleno" (ibidem, p. 117).

A potência política percebida em "Irmãos de Sangue" se deve, em parte significativa, ao desejo da companhia de tornar pleno, segundo a concepção de Lepecki, o encontro com seus espectadores. Para tanto, seus idealizadores utilizam diversos meios pertencentes à natureza da cena, tais como a relação com os bonecos, elementos cenográficos, figurinos, iluminação e trilha sonora, como também algumas escolhas determinantes que fazem, a exemplo da supressão da palavra falada e consequente destaque ao trabalho corporal e, ainda, a utilização de uma maquinaria conduzida artesanalmente pelos próprios atores durante a encenação e pelo contrarregra contratado. Como reconhece Pessoa (2018), há aí "a opção por um trabalho realizado corporalmente em detrimento a um que utilize, na busca pelo efeito desejado, mecanismos tecnológicos". Como conseqüência dessa escolha, percebemos que a "complexidade que se estabelece no momento da encenação é fruto de um processo longo e exaustivo de ensaios e treinamentos, determinados pelo rigor técnico, almejando a potência do encontro" (PESSOA, 2018, p. 79).

São esses aspectos, que, em meio às características do trabalho da companhia, promovem uma transgressão como ato ético-político. Podemos perceber, ao refletir sobre tais elementos, uma interessante aproximação com a obra de Óscar Cornago, a qual nos auxilia na tessitura de relações entre ética e política na dimensão do corpo e da experimentação e nos conduz ao aprofundamento do debate sobre a questão do encontro. O filósofo espanhol se dedicou a tais questões, de modo muito significativo, em "Éticas del cuerpo" (CORNAGO, 2008), criando, assim, relevante contribuição à área das Artes Cênicas.

Na obra de Cornago, temos ética e corpo como conceitos inseparáveis. Para o autor, cada cultura afirma um modo de entender seu corpo e seu lugar no espaço público; é o corpo o elemento que produz a verdade e é também ob- 
jeto de intervenções políticas. Assim, o corpo possibilita um ato de repensar os contornos do político: para o filósofo, o político não se estabelece a partir da vã oposição, fortemente marcada até os anos sessenta, entre racional e irracional (e, consequentemente, pensamento e corpo humano), mas, sim, da conversão do corpo em encontro com o outro.

O caráter relacional existente em todo encontro com o outro, aqui destacado a partir do pensamento de Cornago, nos provoca a pensarmos sobre o fluxo entre corpo, ética e política. O corpo, quando compreendido como relação, como encontro, é palco de discussão, confronto e compartilhamento de afeto que mobiliza, ou seja, ele é ético e é político. O filósofo afirma que "a história das práticas cênicas está vinculada às relações entre corpo e sociedade" (CORNAGO, 2008, p. 52). Com isso, evidencia que, ao voltar a tornar explícito o espaço social, hoje compreendido a partir do corpo, porém, sem que um se dilua no outro, a cena contemporânea cria uma política que se exprime a partir da proximidade.

Os compromissos com ideologias, partidos e instituições que serviram para articular a história no século passado, que promoveram o nascimento da identidade de diversos grupos teatrais dos anos de 1960 e 1970, se convertem, segundo o autor, em outro tipo de compromisso desde o fim do século e começo dos anos dois mil. Então, começa a se evidenciar aí uma política a partir do mínimo do próprio corpo. Esse processo de revisão ética, em que um confronto com o outro proporciona que o espaço do privado fique ligado ao social, alcança também as encenações artísticas, para Cornago.

Vale lembrar que a potencialização da noção de relação com o outro, aqui sinalizada pelo filósofo espanhol, e percebida, no contexto desta escrita, no trabalho da Cie Dos à Deux, não se restringe a um ou outro estilo de encenação: reside no processo de criação. Assim, ela se evidencia em cada obra da companhia, de diferentes maneiras. Porém, não há nenhum tipo de determinação de que o olhar às relações seja condição necessária à existência de coletivos teatrais. A potencialização da relação com o outro e as diversas experiências que daí emergem aqui interessam, todavia, pois são geradoras de discurso e determinantes à poética singular de diferentes agrupamentos - consequentemente, criam implicações também no plano ético-político.

Ao refletir sobre essa questão já abordada por Cornago, da relação com 
o outro como geradora de consequências no plano ético-político, em conjunto com a análise da experiência da Cie Dos à Deux em "Irmãos de Sangue", foi possível perceber durante a pesquisa desenvolvida, que há, ainda, um fator muito relevante na composição poética da companhia e que, por conseguinte, traz importantes reverberações no plano ético-político de sua cena: a variação encontrada na repetição.

\section{A repetição, a diferença}

Como visto, o trabalho da Cie Dos à Deux nos seus diversos espetáculos se estrutura a partir de algumas evidências que, neste estudo, buscamos elencar: a ausência de texto oral, o investimento no gesto caracterizado pela fricção entre a dança e o teatro e a noção de encontro como desafio. No trabalho da companhia, essas são algumas dentre outras marcas observáveis em uma expressão artística que, desenvolvida a partir da experimentação, tem lógica própria.

Contudo, ainda que possua lógica específica, a ação da companhia não se trata de "um tipo de criação com regras imutáveis: o trabalho não se faz estanque de um espetáculo a outro. Cada nova composição conserva algo de reconhecível com relação à anterior, por certo, mas todas acolhem a variação que emerge de cada processo" (PESSOA, 2018). No caso específico da montagem de "Irmãos de Sangue", André Curti e Artur Luanda Ribeiro reconhecem a descoberta de novas facetas do caminho de composição:

André Curti - [...] a gente se sentia bem nessa linguagem que 'estava se construindo [...], só que o medo [...], que "É, não, mas não é por aí, está muito teatral, está muito parado..." [...]. Só que, isso, com o processo, veio se afirmando cada vez mais e de forma muito evidente e aí [...] a gente aceitou [...]. No "Fragmentos" ${ }^{3}$ a gente também se confrontou com o novo, tivemos também muito medo, mas também assumimos. Artur Luanda Ribeiro - Acho [que] com menos conflito, porque era tão forte a mudança que a gente não tinha medo. André Curti - Mas era porque a gente queria essa mudança. Era o desejo de sair de [...] um determinado tipo de linguagem pra ir pra outro [...]. Então a gente tinha menos conflito e esse ["Irmãos de Sangue"], ele se apresentou dessa maneira e a gente não soube, desde o começo, acreditar. Mas porque somos exigentes, somos loucos, somos perfeccionistas [...].

${ }^{3}$ Espetáculo da Cie Dos à Deux. Ficha técnica: roteiro, encenação e coreografia: Artur Ribeiro e André Curti; elenco: Maria Adelia, Matías Chebel, André Curti e Artur Ribeiro; música original: Fernando Mota; acessórios, perucas e máscaras: Maria Adelia; figurino: Hervé Poeydomenge; cenografia: Artur Ribeiro e André Curti; cenário e objetos: Démis Boussu; iluminação: Thierry Alexandre e Artur Ribeiro; marionetes: Fuliang MA e Maria Adelia; realização de imagens e edição: Jean-Luc Daniel; fotografia: Xavier Cantant; design gráfico: Roberta de Freitas; direção de produção: Nathalie Redant. Ano de estreia: 2009. Informações disponíveis em link do website da companhia:

http://www.dosadeux.com/spip.php?article401\&lang=fr. Último acesso: 30.08.2019, às 13h12min. 
Na entrevista com os atores, é perceptível um espanto com a própria obra em criação a partir das diferenças observadas no processo de montagem de "Irmãos de Sangue" com relação às anteriores. Segundo seu relato, no decorrer dos ensaios, compreenderam gradativamente que as propostas emergentes da elaboração das cenas concediam um caráter mais "teatral", como reconhece André, e, logo, mais "parado" em sua visão. Por outro lado, também mais prazeroso. $\mathrm{O}$ ator relatou, durante a entrevista concedida que, desde o primeiro ensaio houve um prazer físico que nenhuma outra criação teve. E por este motivo fala em um tipo de evidência. Narra que foi um longo processo de improvisação, em que ficaram em residência num teatro, o tempo todo atuando como personagens, o que trouxe a composição do universo do espetáculo de modo surpreendente também para seus criadores. Ainda que tenha havido uma desconfiança inicial com o rumo que a criação tomou, como vimos, podemos perceber também em suas palavras, assim como nas de Artur, que a força da mudança foi o que trouxe a necessária coragem frente ao desconhecido.

O desejo da companhia por variações a cada novo espetáculo, o fato de buscar modificação nas estratégias de abordagem à própria criação, como é o caso da residência artística mencionada, em nome da exigência que possuem com a própria composição, aliados ao engajamento necessário ao processo são os elementos que garantem a qualidade encontrada e a emergência da confiança gradativa na composição do resultado. (PESSOA, 2018, p. 106.)

No trabalho da Cie Dos à Deux, a busca pelas diferenças a cada processo se refere ao desejo de não estabelecer, entre seus espetáculos, uma identidade fixada, ainda que o conjunto de encenações se trate de um só corpo, que passa por uma espécie de reinauguração a cada estreia. Tais observações sobre a companhia encontram reverberação teórica em "Diferença e Repetição" (DELEUZE, 2002). Na obra, Gilles Deleuze estabelece uma densa teorização sobre a repetição compreendida como um espelho em que são refletidas diferenças e singularidades. $\mathrm{O}$ filósofo cria, em sua explanação, uma distinção entre as noções de "repetição" e "generalidade". A generalidade, afirma, exprime um ponto de vista de acordo com o qual um termo pode ser trocado por outro, substituído.

A repetição, por sua vez, é uma conduta necessária e fundada exclusivamente em relação ao que não pode ser substituído. Ela diz respeito a uma singularidade insubstituível, como as almas, os ecos, os reflexos ou os gêmeos, os quais não estão no âmbito da semelhança, nem mesmo da equivalência. Portanto, de um lado está a generalidade e, do outro, a repetição. Com isso, para o filósofo, uma obra de arte se repete como "singularidade sem conceito" 
(DELEUZE, 2002, p. 22). Para o autor, é um erro esperar a repetição da lei da natureza e, assim, a espera por uma lei que possibilite a repetição é um sonho que se relaciona à expectativa pela lei moral: a vontade de uma fidelidade que deveria ser retomada numa vida cotidiana, o anseio de que haja sempre uma tarefa a recomeçar.

No trabalho da Cie Dos à Deux se verifica um exercício constante de confronto com a própria criação, que podemos reconhecer como um desejo de não se vincular a esse processo que Deleuze classifica como generalidade. Compreendemos, assim, que a busca por uma criação que se estruture na repetição é um dos aspectos da composição ética da companhia. Para isso, muitas vezes se diluem algumas ideias criativas que, embora aparentemente pudessem funcionar como geradoras de sentido no espetáculo em composição, dado que já experimentadas em ocasiões anteriores da trajetória da companhia, quando são testadas em uma nova elaboração, em um novo espetáculo, não apresentam o resultado esperado.

André Curti - É o "não medo" de jogar fora, né, que eu acho que isso também é uma coisa que a gente trabalhou... você cria um objeto maravilhoso e ele não encaixa [...], aí não adianta você brigar pra deixá-lo [permanecer], porque não tem lugar pra ele. [...] existe essa noção de desapego [...]. Então, é pegar [...] o que é determinante. Artur Luanda Ribeiro - E [decidir] se vai pôr, porque se cria [...] muita coisa. Criamos coreografias perfeitamente fechadas e que, quando elas estão prontas, a gente não faz. [...] ah, já teve momentos, na véspera do espetáculo, coisas, cenas ótimas, "tinindo", ensaiamos sete meses: "Corta". Tem aqueles cinco minutos, mas...

No trecho selecionado acima, os fundadores da Cie Dos à Deux relatam o processo de se desfazerem do que percebem que, de alguma forma, não contribui à obra em criação, ainda que, em algum momento anterior, possa ter colaborado. Com isso, uma vez mais não se deixam fixar pela generalização pretendida pela regra moral. Deleuze afirma como necessário o estabelecimento da oposição entre a repetição e a lei moral, para que se possa fazer dela o pensamento do "para além do bem e do mal" (ibidem, p. 29). O filósofo explana, assim, a prova da repetição na lei moral através do conceito de "eterno retorno", elucidado abaixo.

Oeternoretornodiz: Oquequiseres, queira-odetalmaneiraquetambémqueirasseueterno retorno. Há aí um 'formalismo' que reverte Kant em seu próprio terreno, uma prova que vai mais longe, pois, em vez de relacionar a repetição com uma suposta lei moral, parece fazer da própria repetição a única forma de uma lei para além da moral. (DELEUZE, 2002, p. 29.) 
Ao refletirmos sobre o trabalho da Cie Dos à Deux, podemos inferir que, em diversos momentos de sua trajetória, a prova do eterno retorno se fez presente. A maneira de lidar com cada situação consiste em algo sempre cambiante. Um exemplo que aqui pode ser destacado é o que diz respeito à escolha de Artur Luanda Ribeiro, de assumir, além das funções exercidas desde a fundação da companhia, de idealizador, diretor e ator, também aquela de iluminador, em busca de potencializar o trabalho desenvolvido.

Artur Luanda Ribeiro - [...] as nossas turnês eram, às vezes, em lugares inóspi-
tos, em condições complicadas [...] a gente vai pra África, foi pra Rússia, Balcãs, en-
fim. Eu fui percebendo que [...] se eu desse um upgrade nessa técnica, eu poderia
entender até os atrasos que levavam a gente, às vezes, a entrar em cena sem se aque-
cer - e isso né, levava a gente a um estresse físico muito grande [...]. Então, isso foi
a primeira etapa: entender porque a gente 'tava sempre atrasado; e aí quando eu co-
mecei a entender [...] a parte técnica, logicamente que vem a parte artística [...]. En-
tão, quando a gente começa a criar um espetáculo, eu já tenho um olhar comple-
tamente de iluminador, que é: "o que eu vou iluminar, [...] colocar em valor [...]".

No trecho selecionado acima, fica evidente que a trajetória da companhia se faz em movimento de fluxo constante: de diálogo, de escuta das necessidades dos criadores e daquelas pertinentes a cada obra, de observação e, ainda, de ação e reação à criação como um todo, ou seja, à composição que se desenvolve para além de cada espetáculo.

Existe a possibilidade de que um processo como esse, fundado na noção de movimento, advenha da origem própria do encontro entre os fundadores Artur e André, os quais possuem sólida formação em dança e teatro, anterior mesmo à criação da Cie Dos à Deux. Significa dizer que a composição da dupla é algo que já nasce contaminado pelas noções de movimento e hibridização. Isso se traduz em cada encenação e, ainda, se reflete no cotidiano criativo da companhia. Provavelmente se trate do elemento fundamental que possibilita a emergência de um processo de criação que, embora se dê de modo contínuo, não recai na generalidade.

Ao considerar como referência importante ao trabalho desse coletivo o exercício do diálogo e o entrelaçamento dos diferentes elementos artísticos na prática cênica, assim como a escuta às necessidades pertinentes a cada obra, destaco, no trecho abaixo, a descrição dos atores entrevistados sobre a constituição de seu trabalho, a partir da imagem de uma espécie de "fio de navalha", segundo as palavras de Artur. Essa imagem é o meio que provoca os atores a constituírem seus processos criativos fundamentados na noção de repetição. 
Por uma necessidade de estarem sempre em uma espécie de estado de alerta durante a execução das encenações, dada a complexidade e risco das criações, não há espaço para recaírem em um processo de generalização.

\begin{abstract}
Artur Luanda Ribeiro - [...] você se equilibra, né, no fio da navalha, se você escorregar, né, é uma navalha. Então, eu acho que a gente tem um pouco isso e isso tá no jogo, tem o lirismo, mas, ao mesmo tempo, pode ser clown [...], tem várias coisas que são no fio da navalha. É trágico, mas não pode ser melodramático, porque a imagem já é trágica [...]. Então, é toda uma modulação de interpretação que é muito sutil [...], porque senão pode ficar tudo ao pé da letra: a engraçada é engraçada, a tragédia é tragédia, e não é isso [...]. André Curti - É, [...] mas é também porque a gente não recorre a recursos [...] Artur Luanda Ribeiro - $\quad$ Tecnológicos. André Curti - Tecnológicos, ou seja, existe uma fragilidade, que é a fragilidade que tudo depende da gente [...]. [...] no começo, é difícil, porque o ator, pra conseguir, [precisa] justamente, tá no jogo dele e orquestrando tudo isso [...].
\end{abstract}

No trecho destacado, a dupla de atores evidencia a complexa rede de elementos que gerencia, durante o ato criativo e, posteriormente, durante a execução dos seus espetáculos, sem recorrer à tecnologia: interessa à poética da Dos à Deux que os corpos se atritem com os demais elementos. Essa complexidade potencializa a relação entre o corpo que se compõe (que inclui o encontro entre os elementos cênicos trabalhados, a técnica desenvolvida, o espaço utilizado, o tempo e a disposição dispensados à criação) e a trajetória que se desenvolve com o passar dos anos - e é percebida, na entrevista, como maturidade de trabalho.

No caminho poético desenvolvido, podemos notar que há uma base sólida em cada espetáculo, composta por movimentações específicas executadas pelos atores. Embora haja uma estrutura que contempla as movimentações, essa não impede que as percepções sensoriais se manifestem, ou seja, possibilita o jogo com a respiração que se renova a cada noite, a cada novo público. Esse, por sua vez, promove que o corpo que se compõe entre todos os elementos na situação do desenvolvimento do espetáculo ao vivo inclua todos os fatores que afetarão e serão afetados pelos atores. Assim, se verifica um tipo de repetição que, embora conte com dados específicos recorrentes de um ensaio para o seguinte, e, ainda, de uma apresentação para a próxima, busca que a experiência de composição de um corpo se potencialize, deixando emergir algo novo naquilo que parece ser o mesmo, diariamente. A cada dia de ensaio e a cada noite de espetáculo, a repetição gera novas questões e percepções, ou seja, gera novas experiências. 


\section{Dois aspectos: a técnica e o saber}

O conjunto das experiências adquiridas pela Cie Dos à Deux e aqui analisadas é exatamente aquilo que confere à companhia o poder de cumprir sua atuação ética e política nos contextos em que se inserem. Tais experiências não estão vinculadas apenas no âmbito da técnica, mas em dois aspectos, sendo a técnica um deles. O outro, como podemos verificar no trecho selecionado abaixo, se trata do desenvolvimento cultural que reúne o saber sobre a própria experiência e o olhar ao mundo em que a companhia se insere.

Artur Luanda Ribeiro - $[\ldots]$ é o tempo de técnica $[\ldots]$... Então, o treino, ele é necessá-
rio para que o corpo continue vivo, mas foi tanto trabalho que tem uma técnica pro-
funda $[\ldots]$, com a musculatura $[\ldots]$, como se a gente tivesse afinado [...]. [...] pra
cada fase, tem um patamar, [...] senão você está correndo o tempo inteiro, você tem
$[\ldots]$ até olhar, ver o trajeto que você fez, pra você dar a importância daquilo... [...] o
aprendizado está ligado à cultura também, né, então [...] é um olhar, é um entendi-
mento, é a leitura do olhar estético, o olhar cultural de, enfim, de perceber a plurali-
dade, né, da nossa existência, né e você vai, na verdade, absorvendo cores e aí a gente
pode ter um paralelo com o pintor, são várias fases do pintor $[\ldots]$, não é só técnica,
é vivência de vida, como ser humano também, de como você olha pro mundo $[\ldots]$...

Com o trecho acima selecionado, ao refletirmos sobre o duplo encaminhamento que acabamos de perceber como definidor ao trabalho da Dos à Deux, sendo um deles o da técnica desenvolvida e, o outro, o olhar atento ao mundo que promove um constante desenvolvimento cultural, ambos destacados a partir do tratamento da questão da repetição, podemos notar que alguns fatores específicos proporcionam a potência cênica da companhia e a percepção aqui desenvolvida sobre a noção de encontro, destacada a partir do acompanhamento que pude realizar ao trabalho da Dos à Deux: um confronto singular entre dois homens, atores, bailarinos, sedentos pelo exercício do rigor técnico; buscando expandir sua arte em um país estrangeiro"; companheiros de sala de ensaio, de palco, de vida, de postura política, de ação ética descoberta durante a caminhada e, consequentemente, escolhida.

Assim, a partir do exemplo da Cie Dos à Deux, podemos compreender que a ética desenvolvida no seio de um coletivo cênico tem uma implicação política imediata. No caso do grupo analisado, essa implicação diz respeito a um tipo de processo criativo e expressão artística em que a presença do outro afeta e é afetada a todo instante. No modelo de ação desse coletivo, vemos a 
composição de uma ética que se funda a partir da relação com o outro, quer seja este outro uma pessoa, um objeto, um espaço, um tempo, uma sensação, uma parte de corpo ou qualquer elemento que possa provocar algum tipo de estranhamento no corpo em composição. Dado que o tipo de encontro que faz emergir a possibilidade ética aqui verificada se regula justamente na relação entre todos esses outros e no enfrentamento entre eles acirrado pela repetição que evidencia as diferenças, podemos perceber aí um plano possível de confrontarmos o entendimento sobre a ética que o aproxima da moral, afastando esses dois conceitos e aproximando, por conseguinte, os conceitos de ética e política no campo das artes cênicas. 


\section{Referências}

ARISTÓTELES. Ética a Nicômaco. In: Metafísica (Livro I e II); Ética a Nicômaco; Poética. v. 2. Seleção de textos de José Américo Motta Pessanha; Trad. Leonel Vallandro e Gerd Bornheim, da versão inglesa de W.D. Ross. São Paulo: Abril Cultural, 1984, 376p. (Coleção Os Pensadores). ISBN 85-13-00232-1.

CORNAGO, Óscar. Éticas delcuerpo: Juan Domínguez, Marta Galán, Fernando Renjifo. Caracas, Madrid: Editorial Fundamentos, 2008, 382p. ISBN 978-84-245-1146-3.

DELEUZE, Gilles. Diferencia y repetición. Buenos Aires: Amorrortu, 2002, 464p. ISBN 978-950-518-361-6.

LEHMANN, Hans-Thies. Escritura política no texto teatral: ensaios sobre Sófocles, Shakespeare, Kleist, Büchner, Jahnn, Bataille, Brecht, Benjamin, Müller, Schleef / Hans-Thies-Lehmann. São Paulo: Perspectiva, 2009, 413p. ISBN 978-85-273-0874-8.

LEPECKI, André. No metaplano, o encontro. In: Rumos Itaú Cultural Teatro 2010-2012. Org.: SANTO, Cristina E.; FABIÃO, Eleonora; SOBRAL, Sonia. São Paulo: Itaú Cultural, 2013, 156 p. (Coleção Encontro). ISBN 9788579790393.

PESSOA, Desirée. Éticas experimentais nas artes cênicas: um estudo a partir do trabalho dos grupos LUME, Dos à Deux e NEELIC. Tese (Doutorado em Artes Cênicas) - Programa de Pós-Graduação em Artes Cênicas, Centro de Letras e Artes, Universidade Federal do Estado do Rio de Janeiro, Rio de Janeiro, 2018. 